\begin{tabular}{|c|c|c|}
\hline $\begin{array}{l}\text { EXCELLENT } \\
\text { PUBLISHERS } \\
\end{array}$ & 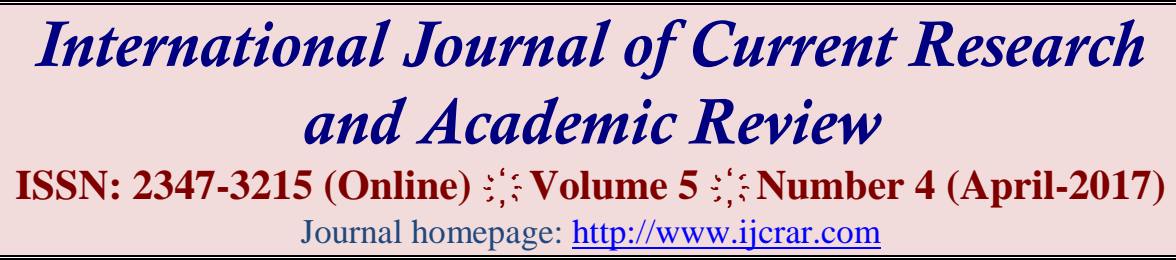 & \\
\hline
\end{tabular}

doi: https://doi.org/10.20546/ijcrar.2017.504.013

\title{
General Features of Pteridophytes (Fern)
}

\author{
Teena Agrawal*, Priyanka Danai and Monika Yadav \\ Department of Bioscience and Biotechnology, Banasthali Vidyapith, Rajasthan, India \\ *Corresponding author
}

\section{Abstract}

Ferns are known to be the first type of vascular plants which are generally considered to be simpler than vascular plants that make seeds. Ferns were traditionally classified in the "Filices" but modern classifications assign them their own phylum i.e. division of the plant kingdom, as "Pteridophyta" or "Filicophyta". Ferns are able to reproduce without using seeds and are seedless vascular plants. They range from very short, unimpressive house plants to larger, full grown trees. They are often used in landscaping and decoration but also occur naturally in a variety of environments. Ferns first appear in the fossil record 360 million years ago in the late Devonian period, but many of the current families and species did not appear until roughly 145 million ago in the early Cretaceous. The fern Osmunda claytoniana is a paramount example of evolutionary stasis. Paleontological evidence indicates it has remained unchanged, even at the level of fossilized nuclei and chromosomes, for at least 180 million years. During this era some fern like groups actually evolved seeds (the seed ferns) making up half of the fern like foliage in Carboniferous forests and much later gives rise to the flowering plants. Most of the ferns of the Carboniferous became extinct but some later evolved into our modern ferns. There are thousands of species in the world today.
\end{abstract}

\section{Article Info}

Accepted: 10 April 2017

Available Online: 20 April 2017

\section{Keywords}

Ferns, Pteridophyta,

Carboniferous, Filicophyta,

Devonian period,

Paleontological evidence.

\section{Introduction}

A fern is a member of a group of about 10,560 known extant species that reproduce via spores and do not consist of spores and flowers. They differentiate from mosses by being vascular i.e. they have certain tissue that conducts water and nutrients. They have branched stems and leaves like other vascular plants. Ferns are known to exist from more than 300 million years and in that time diversification of their form have been phenomenal. They generally grow in many different habitats around the world.

\section{Fern Evolution or Paleobotany of Fern}

Ferns (monilophytes) are an important and ancient component of the Earth's terrestrial biodiversity which are critical due to their species richness, ecological impact, and the unique role they play in the evolution and ecology of land plants (Ranker and Haufler, 2008). Ferns first appear in the fossil record in the earlyCarboniferous period. The "great fern radiation" occurred in the late-Cretaceous (Grewe and Felix, 2013; Karol and Kenneth, 2010). Equisetales are considered as sister to the rest of ferns, Marattiales as sister to leptosporangiate ferns, and Dennstaedtiaceae as sister to the eupolypods (Rothfels et al., 2015). Historically, the leaves of the eusporangiate Marattiaceae and of leptosporangiate ferns have been considered megaphylls, but the great controversy arose on the definition of leaves in the Psilotaceae, Ophioglossaceae and Equisetaceae (Chrysler, 1910; Sen, 1968; Bierhorst, 1971; Kato, 1988; Kenrick and Crane, 1997). 
Currently there is a general consensus that the leaves of lycophytes and euphyllophytes are not homologous and have evolved independently (Kenrick and Crane, 1997). Most morphological and molecular phylogenetic analyses including either living or fossil taxa or both, indicate that lycophytes are the sister group of all other extant vascular plants, which are also called euphyllophytes (Raubeson and Jansen, 1992; Stevenson and Loconte, 1996; Kenrick and Crane, 1997; Pryer et al., 2001; Schneider et al., 2009).

\section{Classification of Pteridophytes}

Pteridophytes are seedless vascular plants which are categorized in four subdivisions.

1) Psilophyta

2) Lycophytes

3) Sphenophyta

4) Pterophyta

\section{Psilophyta}

The class was established in 1917, under the name Psilophyta with only three genera (Rhynia, Horneophyton and Psilophyton) for a group of fossil plants (Crane et al., 2004) from the upper Silurian and Devonian periods which lack true roots leaves but have a vascular system within a branching cylindrical stem. Psilotum grows in Florida woodlands and all members of the division, Psilophyta are considered as tropical plants.

Only two genera of whisk ferns are living today: Psilotum and Tmesipteris. Psilotum is a tropical and subtropical plant that occurs in the extreme southern parts of the United States, whereas Tmesipteris is found in many South Pacific islands. Psilophytes are homosporous and have a nutritionally independent, gametophyte Prothallus that produces antheridia and archegonia. Sperm from the antheridia are released in wet habitats and make their way to the eggs, which are inside the archegonia. The diploid zygote develops into the sporophyte

\section{Lycophytes}

The lycophytes are one of four phyla of seedless plants that have vascular or conducting tissue. There are twelve genera and twelve hundred species of living lycophytes. These include plants known as club mosses and spike mosses and quillwort. The lycophytes first appear in the fossil record in the early Devonian period of the
Paleozoic era, about 400 million years ago. Generally each leaf, or microphyll, is narrow and has an unbranched midvein, in contrast to the leaves of the ferns and seed plants, which generally have branched venation. Gametophytes are bisexual; i.e. the sperm producing antheridia and the egg- producing archegonia occur on the same plant.

Fertilization takes place after a flagellated sperm swims to the archegonium. The embryo, or young sporophyte, consists of a shoot, a root, and a food-absorbing outgrowth called a haustorial foot. Ultimately the sporophyte becomes physiologically independent of the gametophyte, and the latter dies. The sporangia (spore cases) occur singly on the adaxial side (the upper side facing the stem) of the leaf. The lycophytes generally bear cone like structures called strobili, which are tight aggregations of sporophylls (sporangium-bearing leaves).

\section{Sphenophyta}

The plants known as horsetails or scouring rushes belong to the genus Equisetum, the only remaining genus in the phylum Sphenophyta, which is a group of seedless vascular plants. The members of the phylum Sphenophyta, the horsetails, reached their maximum diversity during the late Devonian and Carboniferous periods (life of plant, 2011). Sphenophytes are known to be the Homosphores which produce only one kind of spore. The spores germinate to form small, flattened, green gametophytes under low intensity and high humidity. Production of eggs take place in archegonia, at the bases of upright lobes on the gametophytes, and sperm are produced in antheridia, present on the lobes. The fertilization of eggs occurs in the archegonium by a sperm, forming a zygote which, by continued divisions, develops an embryo within the archegonium. The embryo (young sporophyte) is nourished by the gametophyte until it develops its own shoot and roots. One gametophyte may support two or more young sporophytes before it ultimately dies and decays (Gifford and Mickel, 2010).

\section{Pterophyta}

The Pterophyta consist of the ferns. Ferns serve as the second major stride in the evolutionary worldliness of plants. The division Pterophyta is a class of non-seed plants with a fossil record registered back to the lower Devonian. The distribution consists of about 11,000 living species. While they still reproduce by spores like 
mosses, the ferns add a vascular system i.e. certain organs for carrying fluids throughout the plant. These plants are vascular but do not have seeds or pollen. Ferns adopt to live in environments having low light and approximately high levels of moisture and humidity. For this reason they flourish in tropical forests.

\section{Fern or Fillicophyta}

Ferns are known to be the most diverse group of vascular plants after seed plants. Recently the morphological and phylogenetic study was done which indicates that ferns are the sister group of seed plants (Vasco et al., 2013 and Prayer et al., 2001). The most important dissimilarities between the pteridophytes and the reminder of the vascular plants is that the ferns and their allies do not produce large floral or reproductive structures that give rise to seeds which eventually develop into the next generation of plants (Craft., 1999).

Leaves- The stems of fern are often known as "rhizome", even though they grow underground only in some of the species. Epiphytic species and many of the terrestrial ones have above- ground creeping stolons and can reach upto 20 meters. The green, photosynthetic part of the plant is technically a megaphyll and in ferns, it is often referred to as a frond. New leaves typically enlarge by the unrolling of a tight spiral called a "crozier" or "fiddlehead fern". This uncoiling of the leaf is termed as "circinate venation". Leaves are divided into two types a trophophyll and a sporophyll (Merry wheather, 2012). A trophophyll frond is a vegetative leaf related to the typical green leaves of seed plants that do not produce spores, rather only producing sugars by photosynthesis. A sporophyll frond is a fertile leaf that produces spores borne in sporangia that are usually gathered to form sori (Raven and Eichhom, 2004). The underground nonphotosynthetic structures that take up water and nutrients from soil are always hairy and are structurally very similar to the roots of seed plants (Fern frond, 2014).

\section{Uses of Ferns}

Ferns and their allies are in an extensive division of the Plant Kingdom known as Pteridophyta and they have been about for millions of years. Caius (1935) is supposed to be the first man who has defined medicinal uses of some ferns of India. Ferns bear to be distributed in a misty part of the world but it is not infrequent to find ferns in very dry or critically cold conditions. Ferns are also used by the specialist in Unani system of medicine (Uddin et al.,

1998).

Fig.1 Phylogeny of Fern (Pryer et al., 2004)

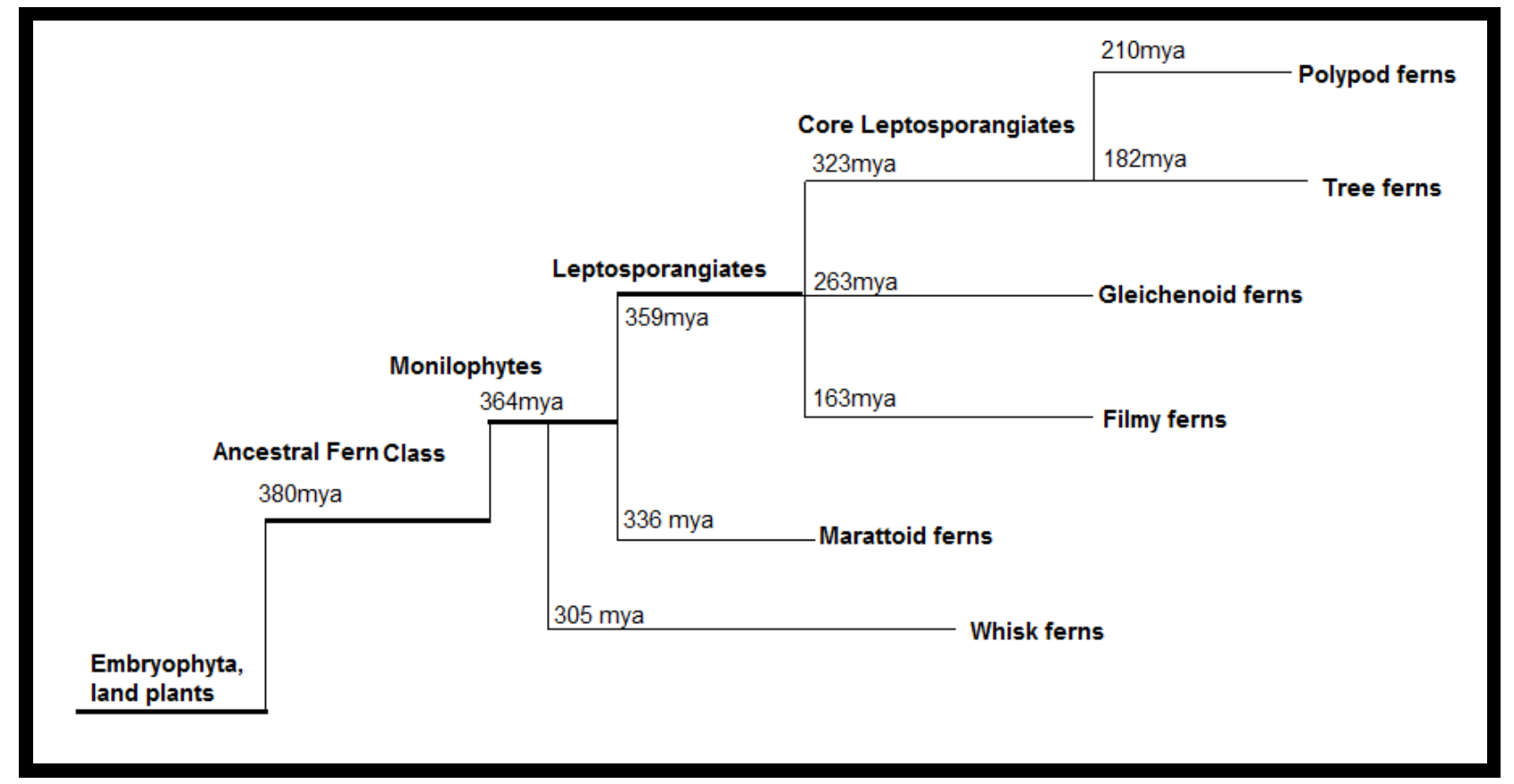


Fig.2 Classification of Pteridophytes (www.plantscience4u.com)

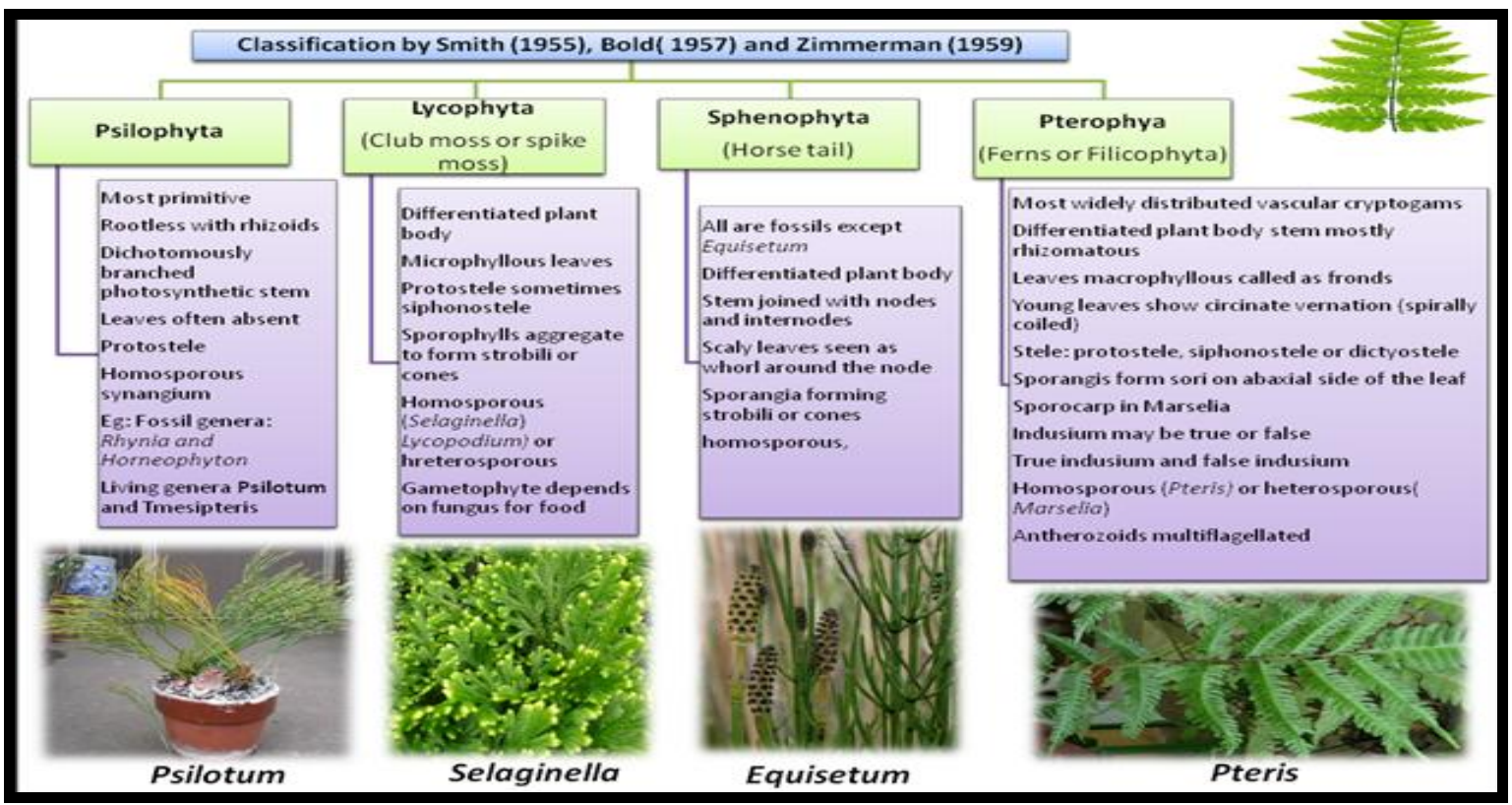

Fig.3 Life cycle of Psilophyta

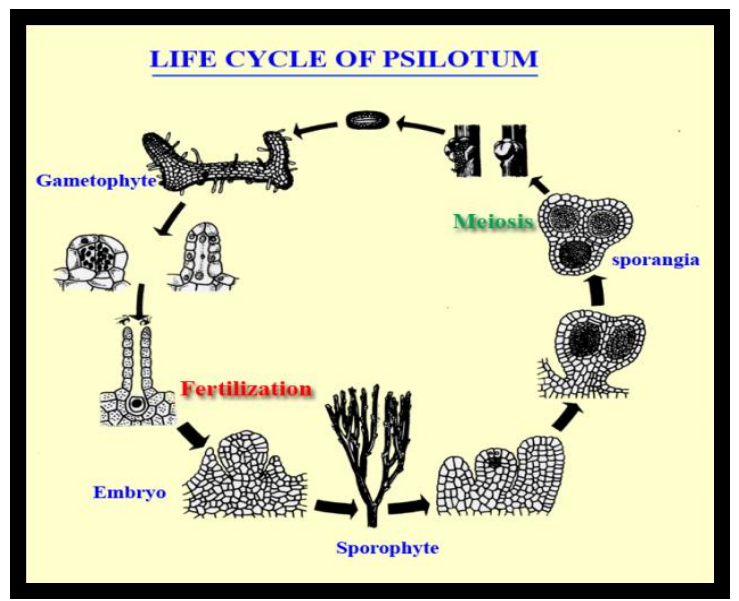

Fig.4 Life cycle of Lycophytes

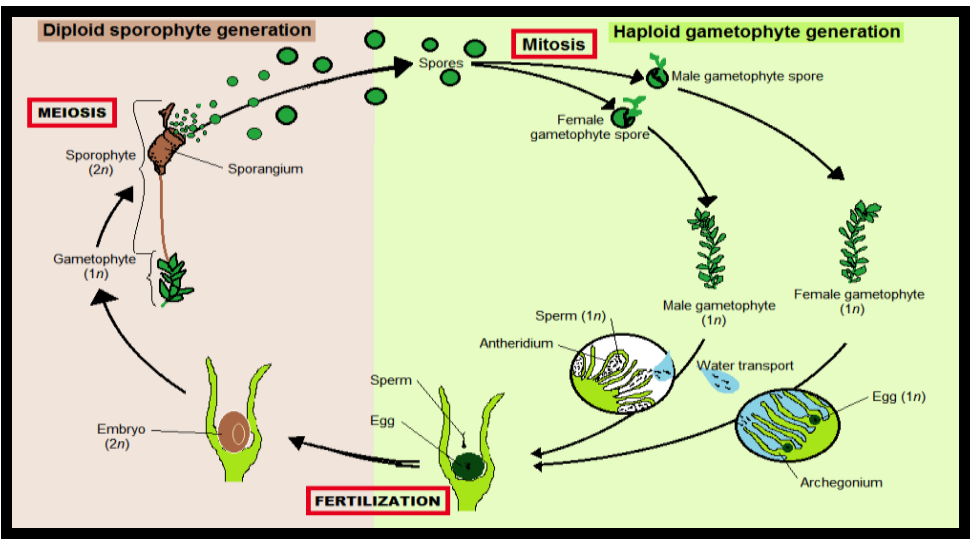


Fig.5 Life cycle of Equisetum

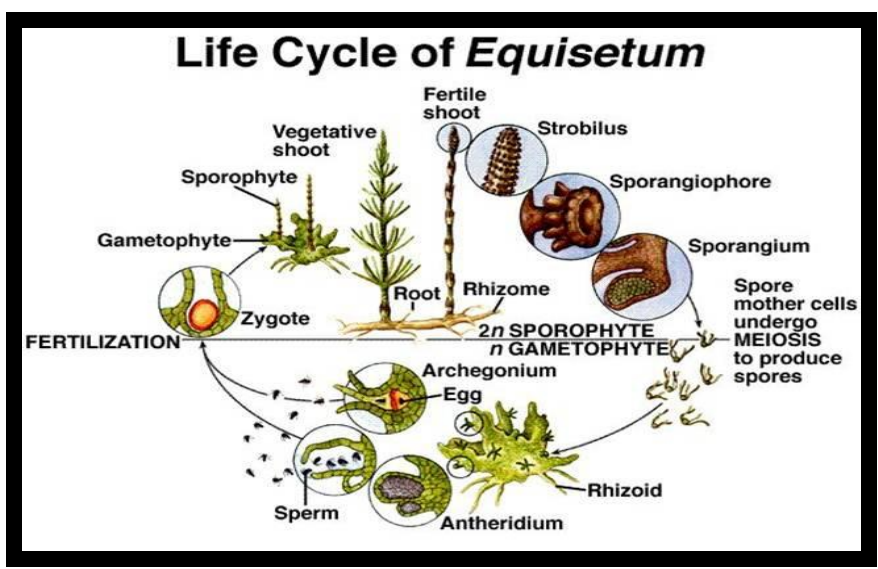

Fig.6 Life cycle of Pterophyta

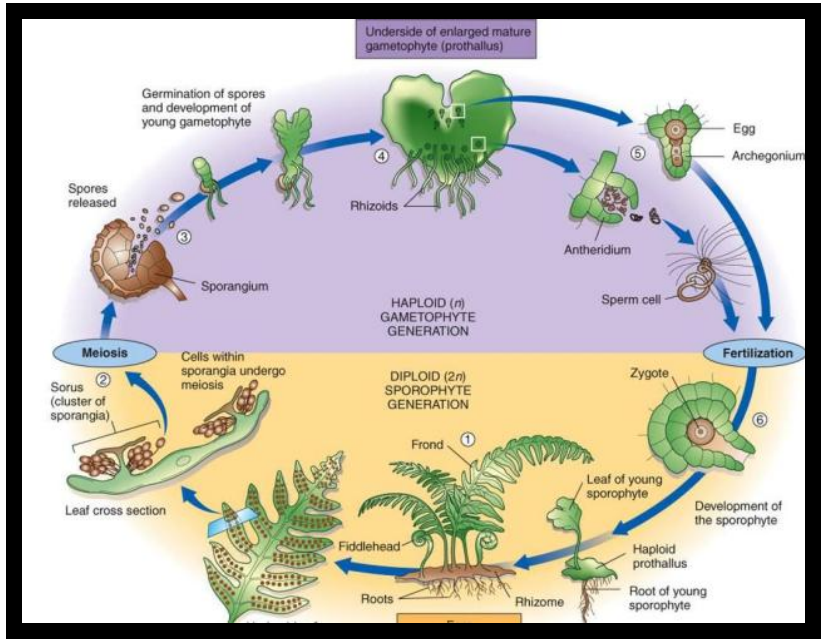

Fig.7 Fern plant show Frond modified

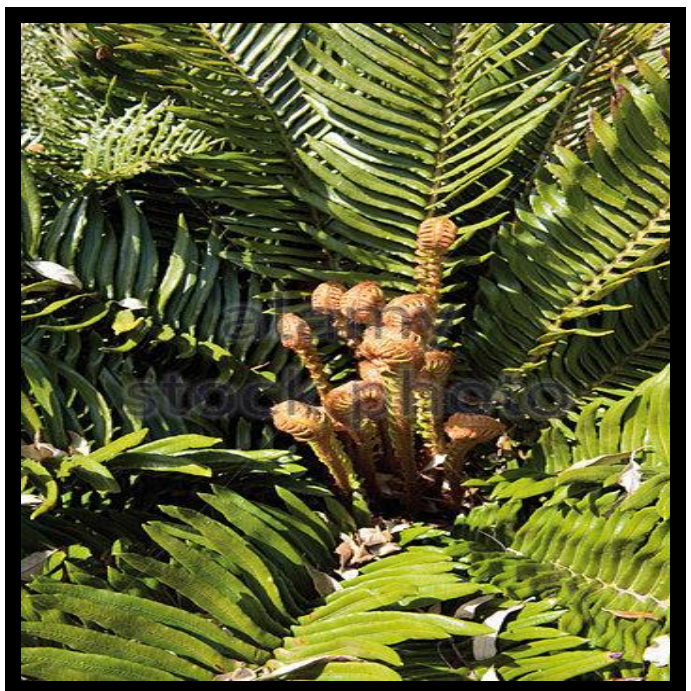

Later, modern biological and pharmaceutical studies were carried out on pteridophytes by various researchers.
Benerjee and Sen (1980) directed the only extensive survey of antibiotic activity among the ferns and 
recorded about a hundred species having such property. Dixit and Vohra (1984) reported edible and medicinally important pteridophytic species from India. In the Chinese system of medicine, many ferns are also recommended by local doctors (Kimura and Noro, 1965).

Edible ferns are some of the most accepted wild food plants collected by people around the world. The fern stems, rhizomes, leaves, young fronds and shoots, and frequently the whole plants are used for food. As early as the 1940s, Athyrium esculentum, Ceratopteris siliquosa, C. pteridoides, Dryopteris prolifera, Pteretis nodulosa, P. esculenta, and Helminthostachys sp. were reported as consumed by the indigenous Filipino (Copela, 1942).

Tree ferns have often been used as food and starch in Hawaii (Leach, 2003). Both young fronds and subterranean stems of Asplenium ensiforme are used for food in the Himalayas. In Malaysia, the Blechnum orientalis rhizomes are eaten, and the fronds of Ceratopteris thalictroides and Diplazium esculentum are used as vegetables. The rhizome and young shoots of Nephrolepis biserrata are edible. Ophioglossum reticulatum is also swallowed as a salad and as a vegetable (Lognay et al., 2008). In India, stems of Angiopteris sp. are eaten for starch.

\section{Acknowledgement}

Authors are thankful to the Banasthali Vidyapith for giving us place to study.

\section{References}

Benerjee, R.D. and Sen, S.P. 1980. Antibiotic activities of pteridophytes. Econ. Bot., 34(2): 284-298.

Bierhorst, D.W. 1971. Morphology of Vascular Plants. New York, NY: Macmillan.

Chrysler, M.A. 1910. The nature of the fertile spike in the Ophioglossaceae, Ann. Bot., 24: 1-18.

Copela, E.B. 1942. Edible ferns, Am. Fern. J., 32(4): 121-126.

Craft, J. 1999. Fern of Australia and PNG.

Crane, P.R., Herendeen, P. \& Friis, E.M. 2004. "Fossils and plant phylogeny", American J. Bot., 91(10): 1683-99, doi:10.3732/ajb.91.10.1683, PMID 21652317.

\section{How to cite this article:}

Teena Agrawal, Priyanka Danai and Monika Yadav. 2017. General Features of Pteridophytes (Fern). Int.J.Curr.Res.Aca.Rev. 5(4), 89-94. doi: https://doi.org/10.20546/ijcrar.2017.504.013
Dixit, R.D. and Vohra, J.N. 1984. A Dictionary of the Pteridophytes of India (Flora of India Series 4), Department of Environment, Government of India, pp. 1-177. Howrah, Botanical Survey of India Publication.

Gifford, E.M. and John, T., Mickel. 2010. Equisetopsida, Encyclopedia Britannica, Inc. http://life of plant.blogspot.in/2011/03/horsetails.html

Kato, M. 1988. The phylogenetic relationship of Ophioglossaceae, Taxon, 37: 381-386 10.2307/1222147.

Kenrick, P., Crane, P.R. 1997. The Origin and Early Diversification of Land Plants: A Cladistic Study. Washington, DC: Smithsonian Institution Press.

Kimura, K. and Noro, Y. 1965. Pharmacognostical studies on Chinese drug "Gu-sui-bu." I. consideration on "Gu-sui-bu" in old herbals (Pharmacognostical studies on fern drugs XI. Syoy akugaku Zasshi, 19: 25-31.

Leach, H. 2003. Fern consumption in Aotearoa and its oceanic precedents. J. Polyn. Soc., 112(2): 141-156.

Lognay, G., Haubruge, E., Delcarte, E., Wathelet, B., Mathieu, F., Marlier, M., et al. 2008. Ophioglossum polyphyllum A. Braun in Seub. Ophioglossaceae, Pteridophyta), a rare potherb in south central Tibet (T. A. R., P. R. China. Geo Eco Trop., 32: 9-16.

Merryweather, J., Robert, C. and Evans A. 2012. What's that fern.

Prayer, K.M., Schneider, H., Smith, A.R., Cranfill, R., Walf, P.G., Hunt, J.S. and Sips, S.D. 2001. Horsetails and ferns are a monophyletic group and closest living relative to seed plant, 409: 618- 622.

Raven, Eichhorn, R. 2004. The Biology of Plants (7th ed. New York, New York: W.H. Freeman and Company.

Sen, U. 1968. Morphology and anatomy of Ophioglossum reticulatum. Can. J. Bot., 46: 957968 10.1139/b68-128.

Uddin, M.G., Mirza, M.M., and Pasha, M.K. 1998. The medicinal uses of pteridophytes of Bangladesh. Bangladesh J. Plant Taxon., 5(2): 29-41. www.plantscience 4 u.com/2014/03/Classification of pteridophytes by $1118 . h \mathrm{tml}$

Vasco, A., Barbara, R.M. and Ambrose, A. 2013. The evolution, morphology and development of ferns leave, 4: 345. 